\title{
The Routledge Companion to
} Embodied Music
Interaction

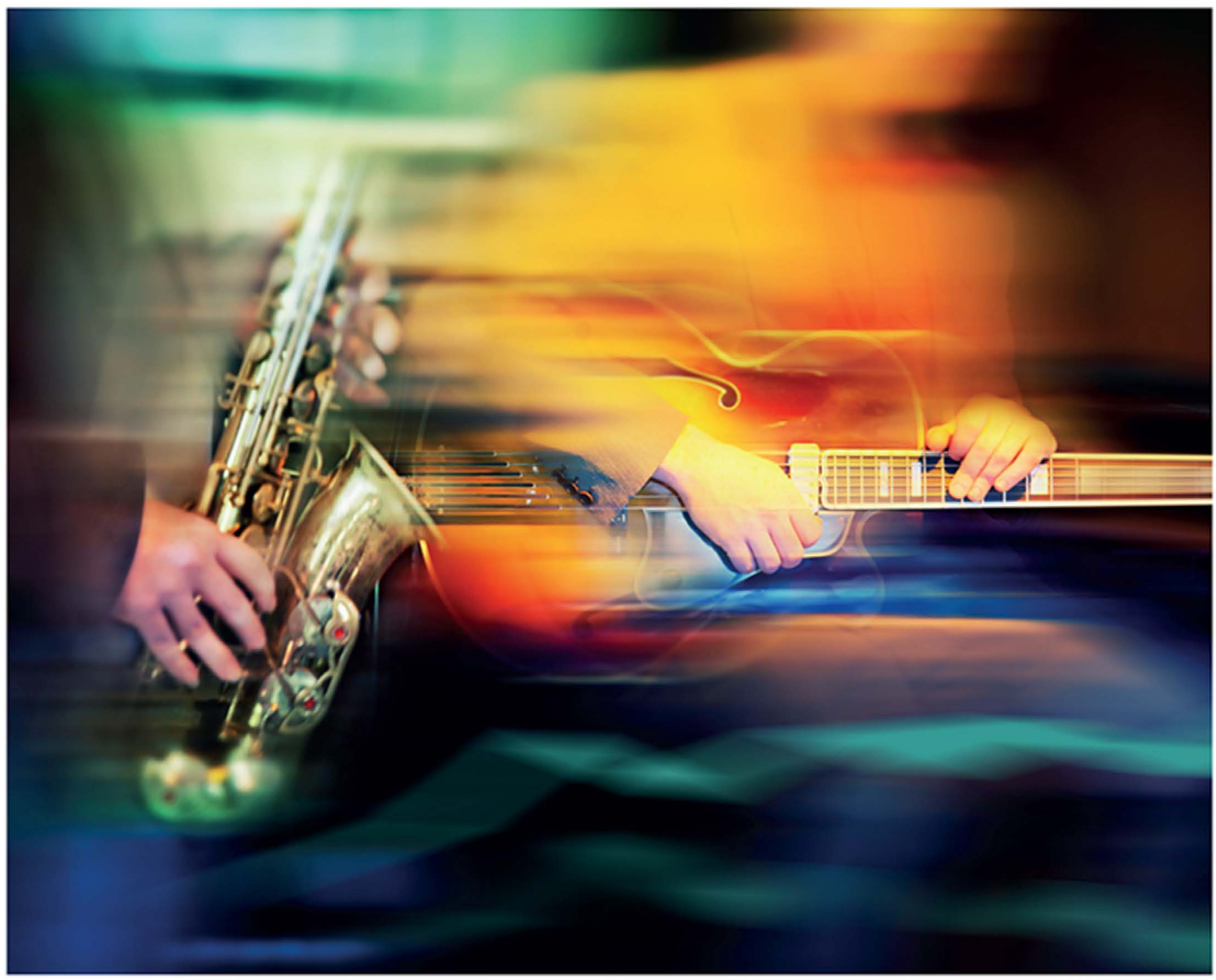

Edited by Micheline Lesaffre, Pieter-Jan Maes, and Marc Leman 


\section{THE ROUTLEDGE COMPANION TO EMBODIED MUSIC INTERACTION}

The Routledge Companion to Embodied Music Interaction captures a new paradigm in the study of music interaction, as a wave of recent research focuses on the role of the human body in musical experiences. This volume brings together a broad collection of work that explores all aspects of this new approach to understanding how we interact with music, addressing the issues that have roused the curiosities of scientists for ages: to understand the complex and multi-faceted way in which music manifests itself not just as sound but also as a variety of cultural styles, not just as experience but also as awareness of that experience.

With contributions from an interdisciplinary and international array of scholars, including both empirical and theoretical perspectives, the Companion explores an equally impressive array of topics, including:

- Dynamical music interaction theories and concepts

- Expressive gestural interaction

- Social music interaction

- Sociological and anthropological approaches

- Empowering health and well-being

- Modeling music interaction

- Music-based interaction technologies and applications

This book is a vital resource for anyone seeking to understand human interaction with music from an embodied perspective.

Micheline Lesaffre is postdoctoral researcher in music and well-being at Ghent University, Belgium.

Pieter-Jan Maes is postdoctoral researcher in systematic musicology at Ghent University, Belgium.

Marc Leman is Methusalem research professor in systematic musicology at Ghent University, Belgium. 
$\because$ Taylor \& Francis Taylor \& Francis Group http://taylorandfrancis.com 


\title{
THE ROUTLEDGE COMPANION TO EMBODIED MUSIC INTERACTION
}

\author{
Edited by Micheline Lesaffre, \\ Pieter-Jan Maes, and Marc Leman
}

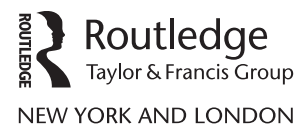


First published 2017

by Routledge

711 Third Avenue, New York, NY 10017

and by Routledge

2 Park Square, Milton Park, Abingdon, Oxon OX14 4RN

Routledge is an imprint of the Taylor \& Francis Group, an informa business

(C) 2017 Taylor \& Francis

The right of the editors to be identified as the authors of the editorial material, and of the authors for their individual chapters, has been asserted in accordance with sections 77 and 78 of the Copyright, Designs and Patents Act 1988.

All rights reserved. No part of this book may be reprinted or reproduced or utilised in any form or by any electronic, mechanical, or other means, now known or hereafter invented, including photocopying and recording, or in any information storage or retrieval system, without permission in writing from the publishers.

Trademark notice: Product or corporate names may be trademarks or registered trademarks, and are used only for identification and explanation without intent to infringe.

Library of Congress Cataloging-in-Publication Data

Names: Leman, Marc, 1958- editor. | Lesaffre, Micheline, editor. | Maes, Pieter-Jan, editor.

Title: The Routledge companion to embodied music interaction / edited

by Marc Leman, Micheline Lesaffre, and Pieter-Jan Maes.

Description: New York ; London : Routledge, 2017. | Includes bibliographical references and index.

Identifiers: LCCN 2016045972 (print) | LCCN 2016048046 (ebook) |

ISBN 9781138657403 (hardback) | ISBN 9781315621364

Subjects: LCSH: Music-Psychological aspects. | Music-PerformancePsychological aspects.

Classification: LCC ML3830 .R78 2017 (print) | LCC ML3830 (ebook) | DDC $781.1 / 1-\mathrm{dc} 23$

LC record available at https://lccn.loc.gov/2016045972

ISBN: 978-1-138-65740-3 (hbk)

ISBN: 978-1-315-62136-4 (ebk)

Typeset in Bembo

by Apex CoVantage, LLC 